\title{
Land Market and Land Grabbing in Brazil during the Commodity Boom of the 2000s
}

\author{
Georges Flexor* \\ Sergio Pereira Leite**
}

\begin{abstract}
This article analyses the determining factors affecting the land market in Brazil in an international context where the availability of natural resources, essential to satisfy the population worldwide, is again heading the agenda. This scenario provoked a rapid expansion of agribusiness and enhanced international participation based on the relative abundance of natural resources. The first part of this article presents the spatial dynamics surrounding the production of commodities and gives evidence of the sharp increase in land price in Brazil. The second part attempts to understand the factors that affect price dynamics and subsequent effects over capital allocation in the sector, addressing the impact of the recent boom of commodities and rising interest by foreign actors in Brazilian land. The conclusion elaborates on the possible land pricing developments and political unfolding.
\end{abstract}

Keywords: Natural Resources; Land; Land Grabbing; Commodities; Agribusiness.

Due to the sharp increase in the price of agricultural commodities since 2005, the issue surrounding the availability of natural resources essential to satisfy the needs of the population worldwide, such as land and water, is back on the international agenda. Thus, countries where such resources are more abundant, as is the case for Brazil, have gained a strategic position given their capacity for providing food to meet the growing demand worldwide. This article investigates how the increase in the price of food commodities has impacted land market dynamics in Brazil. ${ }^{1}$

One of the central hypotheses is that the food price rise brings about an increase in demand for land in countries that export such goods, as with Brazil, inducing an increase in price of land-related assets in these countries (in the short term). Moreover, following the economic theory of international trade, an increase in the relative price has significant allocative and distributive effects (Feenstra 2015): more resources will be used for export food, and the owner of these resources will benefit from the increase in export. A study by the World Bank, for example, has concluded that the increase in agricultural production

\footnotetext{
* Federal Rural University of Rio de Janeiro (UFRRJ), Rio de Janeiro-RJ, Brazil; gflexor@gmail.com.

** Federal Rural University of Rio de Janeiro (UFRRJ), Rio de Janeiro-RJ, Brazil; sergiopereiraleite@uol.com.br.
} 
and the demand for land is associated with eight commodities: corn, soybean, sugar cane, palm oil, rice, canola, sunflower, and planted forests ${ }^{2}$ (World Bank 2010).

Another important hypothesis is that this practice not only skews economic development, but also fosters new forms of income appropriation that such resources enable, altering significantly the productive and patrimonial logic underpinning the activity. Consequently, and because of the growing demand for food, biofuels, and raw materials, there was an increase in interest in land worldwide (Borras et al 2013; Safransky and Wolford 2011). According to a 2010 study by the World Bank, there has been a huge demand for land all over the world since 2008, making 'territorial dispute' a global phenomenon (World Bank 2010). Before 2008, the transfer of land used for farming was about four million hectares per year. By contrast, between October 2008 and August 2009 more than 45 million hectares were traded, 75\% of which were in Africa alone, and another 3.6 million hectares in Brazil and Argentina, a movement that led to the popularisation of the term 'land grabbing', or 'estrangeirização das terras', in Portuguese. These terms have been used in related literature to characterise a process of appropriation of large plots of land by foreign capital (Cotula 2012; Sauer and Leite 2012). Among the most significant information in the study carried out by the World Bank is the characterization of current demanders of land in the world: a) governments concerned with internal consumption and their difficulty in producing sufficient food for the population, especially after the food crisis in 2008; b) financial companies that see a comparative advantage to invest in land; and c) companies in the agribusiness sector that are hoping to expand their businesses given the highly concentrated levels of trading and processing.

After the food price crisis in 2008, which brought the issue of food safety back, it is hardly surprising that governments, led by China and a number of Middle Eastern countries, became more interested in land acquisition with the purpose of producing food for domestic consumption. However, the type of investments made by the financial sector is noteworthy given its historical rejection of illiquid assets, especially land, an asset associated with low liquidity. The global interest in land in Latin America (especially in Brazil, Argentina, and Uruguay) and in Sub-Saharan Africa has prompted an increase in land prices. These trends have attracted attention from the media in Brazil and placed in the limelight the expansion of so-called 'agribusiness', the attempt to regulate the activities of the sector, the new types of conflicts such as the production of soybean and sugar cane in the Legal Amazon or in indigenous lands, and the purchase of rural properties by foreigners (Heredia et al 2010; Leite and Wesz Jr 2013). ${ }^{3}$

With the purpose of addressing these issues (at least in part), this article analyses the factors affecting the land market in Brazil recently. This is a period characterised, amongst other things, by a rapid growth in agribusiness and by international participation based on the availability of natural resources as strategic assets, such as land and water. The first part of this article presents the spatial dynamics in the production of commodities, giving evidence of the sharp increase in land price in Brazil. The second part is concerned with understanding how land price was affected by the increase in international food prices, and subsequent effects on the allocation of capital in the sector, shedding light on the interest in Brazilian land by foreign actors. Attention is given to the importance of the rural 
sector in the financial logic per se, disconnecting the rural from strict demand for food production. The conclusion considers possible price and political developments.

\section{Expansion of agribusiness and the land market in Brazil: a rapid bailout}

\section{Spatial dynamics in commodity production and related impact on land price}

It is important to retrace the expansion and specialisation trend that has characterised the corporate farming sector over the last three decades, a period that has become known as 'agribusiness' expansion (cf. Delgado 2012; Grynszpan 2009; Heredia et al 2010; Mendonça 2005). In order to describe its characteristics, we resorted to the available data on two crops that play an important role in the configuration of Brazilian agribusiness: soybean (including soybean crushing for the production of bran, oil, and animal feed) and sugar cane (the recent boost of which is associated with ethanol production. Their related yields are significant for the general calculation of domestic production in the sector (GDP) not to mention that these products are crucial commodities in the export agenda, fuelling the export drive associated with the rural environment (Delgado 2010).

Figure 1, in the Annex, illustrates how soybean production moved across different areas in the country. Previously concentrated in the South, it later spread to the Cerrado regions, in the Central-West and Minas Gerais states, and in the Northeast. In the 2000s, it expanded to the Amazonian region, especially in Amazon state (in the Humaitá region) and Pará (particularly in the south-eastern and western parts of the state). ${ }^{4}$

The different colours signal the presence of soybean production in Brazilian microand meso-regions (light yellow indicates low levels of production while brown points to the spatial concentration of production) and its expansion towards the north of the country, where the areas with higher production density form a ' $y$ ' shape.

Attention must be given to the particular case of soybean expansion in Mato Grosso state, which in 1990 was producing 3,064,715 tons of grain (as opposed to 6,313,476 tons in Rio Grande do Sul - RS), reaching 8,774,770 tons in 2000 (as opposed to 4,783,895 tons in RS). By 2014, it was producing 26,495,884 tons (as opposed to 13,041,820 tons in RS), according to data from Municipal Agricultural Production/ Brazilian Institute of Geography and Statistics (PAM/IBGE).

It is also worth noting that a similar expansion process over usable areas (areas used both for farming and for environmental preservation) was observed in the case of the biofuel sector producing from sugar cane, showing a sharp increase in areas with sugar cane plantations in the states of São Paulo, Minas Gerais, Mato Grosso do Sul, Goiás, and Paraná (Lima 2010a), as seen in Figure 2. This expansion is mostly due to ethanol production, an important part of the Brazilian Agro-energy Plan (Programa Nacional de Agroenergia) by the Ministry of Agriculture, Livestock and Food Supply (MAPA in its Portuguese abbreviation). The production is concentrated in the southeast (in particular in São Paulo and Minas Gerais) and is spreading into Mato Grosso do Sul, Goiás, and Paraná, to the detriment of more 'traditional' areas used to cultivate this commodity (the north of the state of Rio de Janeiro, the Zona da Mata in Pernambuco, the north of Alagoas, and the 
south of Paraíba). Data collected by the IBGE show that the commercialisation of this product is often connected to its delivery to mills and processing plants, in particular to those linked to the production of sugar and ethanol. Given that the trading routes are usually quite short (differently from the soybean, the product is not exported in natura), they tend to be concentrated in the regions where most plants are located, in particular in the state of São Paulo.

The growing use of land for sugar cane crops, following incentives and (national and international) investments in the production of biofuels, has taken over areas originally used for local food distribution or cattle raising. This is particularly evident in São Paulo state and in the Minas Gerais area of Triângulo Mineiro. When it comes to the expansion towards the Central-West (Goiás and Mato Grosso do Sul), and into the micro-region of Uberlândia, in Minas Gerais, the growth of sugar cane production has to compete with the large-scale production of grains and the agribusiness meat sector (poultry and pork) already established in the area (Lima 2010a). This has translated into a fierce territorial dispute, with some municipalities having to establish a limit to the areas destined for sugar cane.

The soybean chain constitutes one of the most important items in the export agenda of the so-called 'agribusiness' (agriculture, livestock, agri-industry, etc.), even if grain sales outweigh products made with soybean - soybean meal, oil, etc. - which suggests a trend of specialization in the export of products that are less likely to generate added value, thereby increasing the level of external vulnerability. ${ }^{5}$ The recent upturn of surplus revenue in the Brazilian trade balance has been accompanied - and for some analysts, even fuelled - by the movement of agriculture export, prompting an increase in the generation of foreign currencies. For some scholars, as well as for some political actors and for part of the media, this trend has justified an intensification of this strategy (Castro 2010; Furtado 2008), even if this measure translates into increasing debts for the commercial farmers (subsidised by the state), ${ }^{6}$ or higher levels of work exploitation and precariousness (Delgado 2010, 2012). ${ }^{7}$

According to Wilkinson, Reydon, and Sabbato (2012), this expansion is accompanied by the emergence of companies specialised in real estate that are engaged with the 'cleaning, preparation, and sale of new areas for (national and international) private groups, including companies from the grain and sugar cane sectors. Another consequence is the valorisation of land with resulting higher prices.

It is possible to infer that part of this expansion process was enabled by investments in land assets, the origin of which - whether directly or indirectly - was international capital (Leite and Sauer 2011). This strategy corroborates the idea, already put forward by Wilkinson, Reydon, and Sabbato (2012), that international groups (be they corporations, individuals, or governments) who invest resources in the farming sector are focusing on rural real estate (as is the case with projects known as greenfields), rather than solely on activities related to the processing of raw materials, which was previously the case, as we shall see below (Cotula 2012; Safransky and Wolford 2011). 


\section{The land market in Brazil: what recent data reveal about the prices}

In Brazil, investment in land was for a long time a sound alternative to what is described in Portuguese as inversão de capital, or capital expenditure (Brandão 1988), whether to directly promote its valorisation ${ }^{8}$ (with a type of investment that minimises the risk of capital devaluation, even if it does not offer the best profit rates) or to secure access to the heavily subsidised rural credit policy of the 1960s and 1970s (Delgado 2005).

For a brief historical retrospective on the price dynamics of both the purchase and sale of rural real estate, see the timeline by Wilkinson, Reydon, and Sabbato (2012) showing the market downturn following the process of macro-economic stabilisation in Brazil after the adoption of the Real Plan in 1994, a macro-economic strategy to deal with decades of inflation. Towards the second half of the 1990s, the market showed a reflux in the prices of rural real estate, prompting the minister of agriculture at the time to state that 'the structure that supports concentration of land ownership in Brazil has finally collapsed. However, as suggested by some authors, the beginning of the 2000s saw the prices rising again, resulting from the good performance of major commodities prices, especially soybean. This trend intensified after 2007-2008.

According to data from Informa Economics FNP, a consultancy company specialised in the land market in Brazil, the average price for land in the country in 2010 was $\mathrm{R} \$ 4,756.00$ per hectare (Table 1). In 2015, the value went up to 10,083.00 reais. In other words, the average price of land went up by $112 \%$ in only a few years. This amounts to an increase far greater than the variation of the Consumer Price Index Extended (Índice de Preços ao Consumidor - IPCA) of $+48.9 \%$ - or that of the Market General Price Index (Índice Geral de Preços do Mercado - IGPM) of $+52.55 \%$. It is also worth noting that the first quartile of land prices in Brazil registered an increase higher than the inflation for the same period. The range of prices of land assets not only grew at higher rates than the variation in the main price indexes, but has also shown a significant increase since 2010. The interquartile range almost doubled, indicating that the demand for land was more intense in some regions than in others (Flexor 2016).

In effect, from 2010 to 2015, this trend was more intense in the North, Northeast and Central-West (cf. Table 2). In these regions, where agricultural expansion was more intense, ${ }^{9}$ average price variations went beyond $150 \%$, reaching $220 \%$ in the extreme example of the North. In the South $(+131 \%)$ and Southeast $(+130 \%)$, average variations were less intense, even if increase was significant. This trend in prices in the areas of the agricultural frontier, of which the region known as MATOPIBA ${ }^{10}$ is the best known example, is probably the reason for a relatively higher increase in price dispersion in the North and Northeast.

That said, with food prices decreasing in the international market since 2014, the prices of land assets has shown some inflection recently. As Table 1 demonstrates, between 2014 and 2015 the average variation in land price slowed down (almost 9\%), being lower than variations in both the IGPM $(+12.40 \%)$ and the IPCA $(+15.5 \%)$. Moreover, it is noteworthy that the North $(+12.98 \%)$ is the only region where the change in average prices of land is equivalent to the increase in price levels. The main variations in land 
prices were linked to areas that are not highly valued, with prices below $\mathrm{R} \$ 4,000.00$ per hectare. This is the case with the Caatinga area in the Northeast, the forest areas in Espírito Santo, and the flood plains in the North. The main price devaluations affected a broader range of quality and types of land. For example, amongst them there are irrigated areas in the Northeast, pasture land in the North and Mato Grosso, and forest and Caatinga in the Northeast.

In addition, it is worth highlighting that when prices are calculated in dollars, their inflection is more significant for the years 2014-2015 (Table 3). In North American currency, for example, the average land prices decreased by $25 \%$ for this period, a significant drop when compared to the sharp increase of almost $50 \%$ for the period between 2010 and 2014 .

\section{Constraints regarding the shift in prices for land assets}

Given that land supply is inelastic in the short term, prices often depend on factors that determine the demand. Amongst them, soil fertility is important, as well as the location of the land in relation to food consumption markets, the existence of infrastructure and efficient logistical systems, food price, variation of the general prices, existence of taxes on land-related assets, and costs of land market transactions. This is an important set of variables, and they do not affect land prices in similar ways, nor simultaneously. In the next section, we will analyse some of the main factors affecting land price behaviours in Brazil. Focusing on the first hypothesis presented in the introduction, we argue that the rise in food price, a key factor in the boom of commodities in the 2000s, pushes up the price of land, one of the most important resources for the production of food.

In addition, as elaborated in the second hypothesis, we draw attention to how changes in relative prices resulting from this phenomenon fostered further capital allocation for the production of food commodities and land assets in Brazil. The entry of foreign capital in the land market is noteworthy, indicating that the price hike prompted the process. This foreign capital attempted to valorise their assets and expand their capital portfolio, as in the case of pension funds, for example, increasing their participation by means of direct investments and/or investments in association with national corporations in the rural area, seen by those in charge of these investments as 'windows of opportunity'.

\section{Land and commodity prices: a strong correlation}

Figure 3 and Table 4 in the Annex show a strong correlation between the price of land and the prices of commodities. But this correlation is not observed in the case of the inflation rate. Thus, for the period under analysis, during which the general price variation was generally stable and only slightly high, the demand for land was more influenced by its potential as a means of production than as a valuation reserve. Likewise, financial variables show a strong correlation to land prices, making salient the complementarity between land and capital in the production of commodities. The basic monetary rate (CDI - money market interest, Selic - Special Settlement and Custody System), which can serve as a 
proxy for the opportunity cost of land assets and land price, presents a significant inverse relation. On the other hand, the IBOVESPA index, an important financial market index where the weight of corporations in the commodities sector is important, ${ }^{11}$ is positively correlated with land prices. The same argument is valid for the prices of soybean or 33 pounds of beef (the arroba unit of weight). In other words, the prices of land assets present a strong correlation with the prices of commodities, which showed exceptional behaviour in the 2003-2103 decade.

In fact, during the first decade of the 2000s, the prices of the main commodities went up sharply. It is possible to have an idea of this price cycle by observing the movement of the commodity price index of the International Monetary Fund, an index that includes both fuels and agricultural and mining-related commodities (cf. Figure 4).

In January 2001, the value of this index was 61.92 points. Four and a half years later, it reached 100 points, and in August 2008 it was close to 215 points. With the onset of the subprime mortgage crisis - that culminated with the collapse of the Lehman Brothers, the commodity market went through a brief period of low revenues. The commodity index was again below 100 points in February 2009. However, this was a short-lived trend. A year later, the index rose by more than 40 points, and in April 2011, it once again reached the 210 points. Since then, the commodity cycle has (increasingly) shown signs of reaching an end point.

There are two arguments to explain the behaviour of the commodity prices in this last 'supercycle'. The first argument highlights the strong demand prompted by China's intense economic growth, and to a lesser extent, that of India (Gilbert 2010; Baffes and Haniotis 2010). According to this argument, the conjuncture that combined rapid expanding global demand with rather inelastic supply pushed prices up over a long period. The cycle only reached an end when the Chinese economy stopped accelerating and investments to increase supply entered the operating stage. The second argument proposes an analysis that combines the behaviour of monetary authorities and innovations in the financial sector (Du, Cindy and Hayes 2011; Irwin, Sanders and Merrin 2009; Frenkel and Rapetti 2009). Following this line of explanation of the boom of commodities, the monetary policies adopted by the main central banks since the middle of the 2000 s, characterised by historically low interest rates, guaranteed liquidity in abundance. In the pursuit of an attractive return, operators in the financial markets started to invest in markets that had been little affected by the financial dynamics. The traditional markets of commodities became increasingly important to the financial actors. The result was a considerable increase in the purchase of assets backed by commodities in the growing stage of the cycle. As highlighted by Tang and Xiong (2012), the fact that there is a strong correlation between the prices of the main commodities - be they oil, food or minerals - shows that the behaviour of respective prices is not only driven by factors related to supply and demand. It involves financial strategies.

In other words, the increase in food prices is not only due to the increase in demand for food in a context of limited supply. The price hike also reflects the behaviour of the financial markets and the growing inclusion of agricultural commodities in the logic guid- 
ing these markets. In that context, the expansion of financial activities in the 2000s ended up impacting the dynamics of the food and land markets in Brazil.

\section{Supply of farming products and main Brazilian agricultural commodities during the boom}

If the relative price of certain products goes up, it is expected that their production will increase. A simple calculation of the correlation coefficient shows that in the case of grains, this relation was quite consistent during the boom. From 2000 to 2013, the soybean price went from US\$211.83 to US\$ 538.42 per ton, and the total supply went from 32.34 million to 81.50 million tons. Unsurprisingly, the Pearson coefficient showed a strong correlation (0.875) between the prices of soybeans (in dollars) and the volume produced in that period in Brazil. The same happened in the meat sector, another part of agribusiness that benefitted from the boom of commodities. The prices of beef more than doubled, according to data by the World Bank, going from US\$ 1.93 in 2000 to US\$ 4.07 in 2013. This rise in prices was followed by the domestic growth of $101 \%$ in slaughter. In the case of poultry, the rise in price for a kilogram of chicken $(+74.66 \%)$ was followed by a higher than proportional rate of slaughter $(+114 \%)$.

Figure 5 gives evidence for another effect of the rise in the price of grains on supply in Brazil, namely, the fact that the boom of commodities fostered the production of agricultural products for export such as soybean and corn. Taking into consideration the total production for the $2000 / 15$ period, for example, the increase was of $107.98 \%$; in other words, it more than doubled in 15 years. But a significant part of this increase was due to the growth in soybean production $(+197.6 \%)$ and that of corn to a lesser extent $(+100.22 \%)$. On the other hand, a traditional crop such as the black bean, which is very important for the Brazilian diet, showed a much inferior increase in volume $(+22.84 \%)$ even if it registered a significant price variation (+274.51\%) for this period.

The boom of commodities also encouraged sugar production, as mentioned earlier. ${ }^{12}$ Between 2000 and 2013, international prices went up by 142\%, and sugar cane production in Brazil went up by $136 \%$. This rise in supply was due to some improvements in the productivity of sugar cane $(+10 \%)$. However, first and foremost, this was a result of the increase in planted areas, which went from less than 2 million to more than 10 million hectares (+116\%). As in the case of the sugar, it was expected that the rise in prices of commodities would encourage land use to produce grains. In Figure 6, which underlines the map showed previously, it is possible to observe an increase in planted areas for the period between 2000 and 2013. There is also data on the soybean, corn, and beans crops. The total area dedicated to crops of grains in general grew by $50.8 \%$, soybean crops by $116 \%$, and corn by $22 \%$. On the other hand, the amount of land allocated to beans crops decreased by $13.2 \%$. In other words, the increase in the area destined for the production of grains can be almost exclusively explained by the variation in the extent of soybean crops. 


\section{Capital invested in main commodity chains in Brazil}

The boom in international prices not only stimulated land use for the production of agricultural commodities in Brazil, but also impacted the allocation of capital, encouraging investments in the commodity chains. Foreign capital mainly invested in the soybean chain, which is historically more structured than a good portion of other agribusiness chains and dominated by foreign companies - ADM, Bunge, Cargill, and Dreyfus, to mention a few. There are, however, many large Brazilian companies and co-operatives, such as Amaggi, Coamo, or Caramuru, operating in the soy chains. Along with large multinational trading firms, these companies have undertaken important investments in processing units - either by acquiring them from other companies or constructing new units (greenfield) - and logistic systems, many of them in the Central-Western regions of Brazil. These investments greatly contributed to fostering regional economic growth, and it is hardly surprising that the contribution to Brazilian GDP by the Central-West went up 1\% over the decade of 2002 to 2012 , going from $8.8 \%$ to $9.8 \%$ of the national GDP.

In the meat sector, investments were just as significant. That said, the allocation of resources was guided by national capitals financed by the National Bank for Economic and Social Development (BNDES). Besides the implementation of policies to support the establishment of the Brazilian meat industry, the BNDES provided financial resources that facilitated the significant growth of the JBS, one of the largest meatpacker companies in the world, along with Tyson, Cargill, and National Beef. Using an aggressive strategy of asset acquisition, the JBS bought the largest Argentinean meat processing plant (Swift Argentina) in 2005, the third-largest meat company in the United States in 2007 (Swift), and a large American poultry-processing plant (Pilgrim Pride) in 2009. It also made a number of purchases both in Brazil and abroad. The BNDES also supported the expansion of Marfrig, the second-largest meat company in Brazil, and the re-structuring of the BRF, the largest Brazilian pork and poultry processing firm.

The diversity of exports is another characteristic that differentiates the meat sector from the soybean chain. With regards to the latter, China is the main importer. In 2014, exports to this Asian country amounted to more than $70 \%$ of the total value of soybean export sales. By contrast, the meat sector counts with a number of major importers, such as Russia, Venezuela, Hong Kong, and Iran. A similar trend can be found in the poultry sector, with impressive importers from the Middle East (Saudi Arabia, the United Arab Emirates, Egypt), the Far East (China and Hong Kong, South Korea), and Latin America (Venezuela).

The trajectory of the sugar and alcohol industry since the start of the 2000s was equally marked by a sequence of fusions and acquisitions. This process of concentration (and de-nationalisation) was led by both traditional trading firms in the agribusiness - such as Bunge, Cargill, and Louis Dreyfuss - and by large corporations of the energy sector, such as Petrobras, Shell, and others. Dreyfuss, for example, propelled his growth in the sugar and ethanol market by purchasing plants. The outcome of this process is a company, the Biosev, which with 11 plants is capable of crushing 36.4 million tons of sugar cane per year. Bunge followed a similar trajectory, even if its acquisition strategy was slightly de- 
layed, with first purchases happening only in 2006. Today, it manages eight plants with an overall capacity to process 21 million tons of sugar cane.

The interest in ethanol by large oil companies was prompted by the sharp increase in prices of hydrocarbonate in the second half of the 2000s, and by the need to enter into business areas that could enhance their environmental reputation (Wilkinson and Herrera 2010). These represented sufficient incentives to attract the oil giant Shell, which decided to form a partnership with Cosan, one of the largest Brazilian firms in the sugar and alcohol sector, to create Raizen. In order to gain space in the ethanol market, Petrobras also decided to form partnerships and to create a subsidiary, Petrobras Biofuels (Petrobras Biocombustíveis). However, due to the drop in oil prices since 2015, along with a political corruption scandal, the company is currently reviewing its strategy in the sugar and alcohol sector.

Besides these examples, the fusions and acquisitions that have marked the Brazilian agri-food system ${ }^{13}$ since the early 2000s show that Brazil has started to have an increasingly important position in terms of attracting financial resources for food production. As highlighted by Wilkinson (2009), since the beginning of the 2000s, Brazil has emerged as a global source of agricultural supplies and, in that context, it is not surprising that the country attracted more capital as the prices of agricultural commodities went up. Amongst these commodities, the entry of foreign capital for the acquisition of large extensions of land in the country is noteworthy, as we shall see below.

\section{Land grabbing in the context of Brazilian agriculture}

While there has not been a thorough systematic review nationwide, it is possible to infer that foreign investment in the Brazilian primary sector also resulted in the acquisition of large portions of land (Leite and Sauer 2011, 2012). According to research carried out by the Rural Development and Agrarian Studies Centre (Núcleo de Estudos Agrários e Desenvolvimento Rural - NEAD), using the National Rural Registration System (SNCR) of the National Institute for Colonization and Agrarian Reform (INCRA), 34,632 properties were registered by foreigners in 2008 , encompassing an area of 4,037,667 hectares. This is significant considering that these figures do not include the period known as the 'race for land acquisition' following the 2008 crisis (Pretto 2009). It must be noted that $83 \%$ of this total were properties classed as large properties (above 15 'fiscal modules', a measuring unit used in Brazil).

Table 5, extracted from the study by Pretto (2009: 21), illustrates the historical process of acquisition of rural real estate, showing increasing numbers of properties and land registered by foreign individuals and companies. The 1980s, 1990s, and 2000s show the concentration of this trend at, respectively, $29.9 \%, 18.2 \%$ and $18.8 \%$ for the total number of real estate properties registered by foreigners, and $27.9 \%, 25.9 \%$ and $20.1 \%$ for the total area in the registration system.

This land-grabbing process is not recent (Oliveira 2010) and was part of the agricultural expansion towards the North region in the 1970s and 1980s. An important reference in this historical process was the co-operation between Brazil and Japan for the 
implementation of distinct phases of the Program for Japan-Brazilian Cooperation for the Development of Cerrados (PRODECER), created in the 1970s and implemented during the 1970s and 1980s in several regions of the Brazilian Cerrado, especially in the states of Minas Gerais, Goiás, Bahia, and Mato Grosso (Salim 1986).

An update of the data for 2010, using the same registration system elaborated by INCRA, shows the existence of 34,371 rural properties acquired by foreigners, encompassing a total of 4,349,074 hectares, as seen in Table 6. The same table shows that the largest proportion of properties is concentrated in São Paulo state (35.7\% of the total), Paraná (14.9\%), Minas Gerais (7.68\%), and Bahia (6.38\%). If we take the total of the area into account, the picture changes in terms of which states head the list with Mato Grosso state (19.4\% of the total area), Minas Gerais and São Paulo (11.3\% each), and Mato Grosso do Sul (10.9\%). In both cases, the picture coincides significantly with the movement of agricultural expansion.

The largest positive variations in the number of real estate properties between 2008 (Pretto 2009) and mid-2010 (Sauer and Leite 2012) were in the states of Minas Gerais (14.24\%), Roraima (13.79\%), and Rio Grande do Norte (12.28\%). If we consider land that was incorporated, the picture is a different one, with the following states leading the figures: Amazon (with a significant increase of $120 \%$ in the number of areas being registered), Piauí (with 77.7\%), Minas Gerais (with 57.4\%), and Espírito Santo (with 43.9\%). It could be suggested that part of this trend may be associated with the expansion of agribusiness activities, both in the sector of grains and sugar cane and in the mining and forest sectors. $^{14}$

Specialised studies show that there is no clear correlation between Direct Foreign Investment (IED) and the GDP, and that the volume of external resources entering the country for investment can be explained by corporate strategies (multinationals in particular) and by location-related factors, because of specificities of the regions where investments are being made. The information on IED in the 2011 Census (for the 2010 year), carried out by the Brazilian Central Bank, and based on stock values (rather than flow values), indicates that regarding the country of the final investor, the participation of investments were led by North Americans with 18\% of the total registered. The participation of $1.4 \%$ by Chinese investors is noteworthy.

If one takes into account the allocation of the resources, as seen in Table 7 (in the annex), the majority of IEDs correspond to investments in the service sector $(43.3 \%$ of the total) and in the industrial sector (39.8\%). Agriculture only accounts for $1 \%$ of the global stock, and the mining sector for $6.22 \%$. Some recent works have speculated over whether IEDs are directed towards the acquisition of land per se, the process described as land grabbing. It is not easy to obtain such data using Bacen statistics since its detailed information is not available for consultation. However, one can assume that investments in this area are concentrated on the two sub-sectors mentioned above ('agriculture, livestock and related services' and 'extraction of metallic minerals').

Still drawing on the information available on databases, a quick consultation of the Land Matrix databank elucidates the observation noted in Table 8, namely a significant amount of investments in states like Mato Grosso and Bahia in a relatively short period 
of time (2007 to 2014). It must be noted that some of the key drives for such investments were soybean production, sugar cane and cotton, and the forest sector. The registry shows that the capital for the acquisition of these large expanses of land had its origin in countries like Argentina, Canada, the United States, and Japan.

The North American case has attracted international attention through a study led by a group of non-governmental organisations (Rede Social de Justiça e Direitos Humanos et al 2015), where there is evidence that some investments were sponsored by an American pension fund named Teachers Insurance and Annuity Association-College Retirement Equities Fund (TIAA-CREF), while also revealing its association with foreign and national corporations. ${ }^{15} \mathrm{~A}$ report by the pension fund itself indicates the strategic areas for this type of investment, adopting the nomenclature recommended by the World Bank, as so-called 'responsible investments' (TIAA-CREF 2012). A picture of the areas where the pension fund is investing can be seen in Figure 7.

Due to the narrow and insufficient sources of data and information, it is not possible to categorically state that the growing investment of foreign capital in large portions of land in areas known for the expanding production of commodities has directly and exclusively contributed to the incremental price of land and to the concentration of land ownership that characterises the country. However, there is a probability that such a trend may have had an indirect impact on maintaining the high price expectations of land assets, especially in areas where large plots of farming land face inelastic supply. Studies on behavioural finances (Kahneman 2011; Shiller 2015) show that this is a common mechanism in the operation of financial markets.

\section{In conclusion}

This article attempted to show how the sharp increase in the price of commodities after the 2000s, the commodity boom, had an impact on the dynamics of the land market in Brazil. In particular, it highlighted the main effects of the commodity boom on the price behaviour of land assets, the production of grains, and the geopolitical positioning of the country. As a result, it does not come as a surprise that there was an increase in interest by foreign capital, be it agrarian or financial, in buying land in Brazil, even if it is not possible to establish an explicit correlation between the arrival of IED and the increase in prices of rural real estate.

The themes addressed in this article invite a reflection on the role of the state and its capacity to regulate a strategic area, as is the case for the land market. Those are distinct movements that problematise what we could describe as state capacities for development; in other words, the limited capacity by the state to make its control over land transactions more effective. This could be achieved by optimising the registry of transactions themselves, preventing (re)concentration of land in a context where this trend has spawned many conflicts, and carefully evaluating the substantial support given by governmental agencies to the sector's productive (and concentrated) expansion (especially in the areas of infrastructure and financing) (Delgado 2010, 2012). 
With regards to land grabbing, it is important to note that an attempt at regulation was made in 2010 after the decision by the Attorney General of Brazil (Advocacia Geral da União - AGU) to establish limits to the volume of land acquired directly by foreign individuals, companies, or governments (Sauer and Leite 2012). In fact, the ruling was informed by a specific law concerning the matter, passed in 1971, that had stopped being applied during the decades of the 1990s and 2000s in particular, when the race for land was quite fierce. Before then, in 2007, a proposed bill by a member of the lower house, Deputy Beto Faro, had already stipulated similar measures. However, the project is still waiting to be voted on, and without a scheduled date (Chamber of Deputies of Brazil 2007). Following the ruling by AGU, INCRA issued in 2013 the Normative Instruction no. 76, which prescribes the norms for rural acquisition and lease for foreigners. The text is well grounded, and gives the institute a key role in the monitoring of this type of real estate transaction, although over time these measures tend to become less effective due to lack of resources for their application.

Even after the measures above had been taken, international capital continued to be involved in the agricultural (and mineral) sectors, now mediated by national firms and benefitting from the respective legislation surrounding the eligibility for national companies to operate in the country. Moreover, as mentioned in the Introduction, there is strong political pressure for PL 4059/2012 to be passed, which would make the already precarious regulation of the sector even more flexible (Zaia 2016). Arguments deployed by political actors focus on the need to attract new investments in a conjuncture of economic crisis.

With the boom of commodities coming to an end, the macro-economic conditions faced by Brazil (inflation, fiscal adjustments, etc.) are likely to be a great deal more adverse than what has been experienced since the early 2000s. In that context, the demand for land is likely to slow down, along with the capital inflow to purchase land and agri-food assets, regardless of attempts by the state to unleash the process of internationalisation of the land market. In this context of severe crisis and uncertainty, we will probably see other attempts at liberal reforms in sensitive areas such as land assets, reinforcing the pattern of strong economic concentration, and social inequality that has marked the Brazilian economy and society.

\section{Notes}

1 We are specifically referring to agricultural commodities that perform a strategic role of providing food both for human and animal consumption. Obviously, not all food goods are considered to be tradable (as is the case for manioc flour, for example), and not all agricultural commodities are in the food category (as is the case for the textile sector, for instance).

2 Bearing in mind that the Brazilian participation is mainly focused on the three former commodities

3 See, for example, the recent discussion surrounding the proposed bill 4.059/2012, currently going through the legislative process in the lower house (Chamber of Deputies of Brazil 2012; Zaia 2016)

4 See recent bibliography that corroborates this information: Alves (2005), Costa (2012), D. Lima (2010), and M. Lima (2010).

5 With regards to the trading routes, in the soybean case - and having as a reference the data from IBGE the regions with the highest concentration of production correspond to those where trading processes are 
mediated by the industry rather than by co-operatives or 'middlemen', located respectively in the south and north of the country. Thus, a great deal of the soybean produced in the Brazilian region of Cerrado (Mato Grosso, in particular) is destined for industrial processing (as well as for the external market), and part of this production is used as raw material for biodiesel.

6 Given that the institutionalisation of measures to manage risks associated with agricultural production in Brazil is insufficiently developed, a climatic upheaval, for example, can cause an increase in producers' debts. On the other hand, the constant debt renegotiation in the corporate rural sector has been used as leverage for political support by members of the senate and the lower chamber with connections to the rural sector.

7 Although the number of rural workers involved in the expansion of those crops has decreased, these activities are still characterised by controversial work relations, including scenarios that could be described as slave forms of labour, in particular in the production of sugar cane, coffee, cattle-raising and extractive activities. Moreover, informality is still high in rural Brazil.

8 Ignácio Rangel used the idea of a fourth component part of land rent (to complement absolute ground rent, differential rent I, and differential rent II) based on the strong financial valorisation of rural real estate in Brazil. He pioneered the idea that land ownership could be turned into something close to a financial asset, capable of attracting forms of capital interested in avoiding de-indexation of currency values, in particular during the economic crisis in the 1980s (Rangel 1986).

9 This relates to the expansion of soybean crops and cattle raising.

10 These initials refer to the Cerrado region in the north-eastern states of Maranhão, Tocantins, Piauí, and Bahia.

11 Mining and oil firms in particular.

12 In the theory of international trade, the comparative advantage is, conventionally, one of the main reasons to explain trading gains. It is about the opportunity cost involved in producing a good and exporting part of the production in order to import other goods, making the production more efficient and increasing gains obtained by the exporting country. The comparative advantages, put simply, are generally associated with differences in productivity or differing factors between countries (Feenstra 2015).

13 The agri-food system refers to the network of actors involved in the production, distribution, and consumption of food.

14 The handling of this statistical information demands a certain level of caution, given that the registry has shortcomings, as evidenced in the data related to the origin of capital invested in land assets (in the INCRA registry, around $35 \%$ of the information related to this item is either missing or invalid).

15 As noted by Sauer and Leite (2012), the concept of 'national company' should be analysed with caution. In reality, under the veneer of national firms, and benefitting from changes brought about during Fernando Henrique Cardoso's first term in office in the 1990s, there are holdings that are directly controlled by international capital, or by joint ventures that articulate external and domestic capital, as is the case of the Raizen company, managed by Shell and Cosan, already cited here.

\section{References}

Alves, Vicente E L. 2005. 'Barreiras/Luiz Eduardo Magalhães (BA); Balsas (MA); Uruçui/Bom Jesus (PI): as novas cidades para o agronegócio nos cerrados nordestinos’. III Simpósio Nacional de Geografia Agrária. Presidente Prudente: Unesp.

Baffes, John and Tassos Haniotis. 2010. 'Placing the 2006/08 commodity price boom into perspective'. World Bank Policy Research Working Paper No. 5371.

Borras Jr., Saturnino M, Jennifer C Franco, Cristobal Kay and Max Spoor. 2013. 'Land Grabbing in Latin America and the Caribbean'. In: Ben White, Saturnino M Borras Jr, Ruth Hall, Ian Scoones and Wendy Wolford (eds), The New Enclosures: Critical Perspectives on Corporate Land Deals. London and New York: Routledge, pp. 227-254. 
Brandão, Antonio. S. 1988. 'Mercado da terra e estrutura fundiária'. In: Antonio Salazar Pessôa Brandão and Rodolfo Hoffmann (eds), Os principais problemas da agricultura brasileira: análise e sugestões. Rio de Janeiro: PNPE/ IPEA. pp. 139-179.

Castro, Ana C. 2010. 'From catching-up to knowledge governance in the Brazilian agribusiness'. Desenvolvimento em Debate, 1(2): 9-23.

Chamber of Deputies of Brazil. 2007. Projeto de Lei no. 2289, de 2007 do Deputado Beto Faro. Brasilia: Câmara dos Deputados.

. 2012. Projeto de Lei no. 4059, de 2012. Brasilia: Câmara dos Deputados.

Costa, Solange M. 2012. Grãos na floresta: estratégia expansionista do agronegócio na Amazônia. PhD thesis: UFPA/NAEA.

Cotula, Lorenzo. 2012. 'The international political economy of the global land rush: A critical appraisal of trends, scale, geography and drivers'. The Journal of Peasant Studies, 39(3-4): 649-680.

Delgado, Guilherme C. 2005. 'A questão agrária no Brasil, 1950-2003'. In: Frederico Barbosa da Silva and Luciana de Barros Jaccoud (eds), Questão social e políticas sociais no Brasil contemporâneo. Brasília: IPEA: 51-90.

2010. 'Especialização primária como limite ao desenvolvimento'. Desenvolvimento em Debate 1(2): 111-125.

2012. Do capital financeiro da agricultura à economia do agronegócio. Porto Alegre: Editora da UFRGS.

Du, Xiaodong, L Yu Cindy and Dermot J Hayes. 2011. 'Speculation and volatility spillover in the crude oil and agricultural commodity markets: A Bayesian analysis'. Energy Economics, 33(3): 497503.

Feenstra, Robert C. 2015. Advanced international trade: theory and evidence. New Jersey: Princeton University Press.

Flexor, Georges. 2016. 'Commodity Boom and the political economy of land in Brazil 2003-2013', LASA Congress, New York.

Frenkel, Roberto, and Martin Rapetti. 2009. 'A developing country view of the current global crisis: what should not be forgotten and what should be done'. Cambridge Journal of Economics, 33(4): 685-702.

Furtado, João. 2008. 'Muito além da especialização regressiva e da doença holandesa: oportunidades para o desenvolvimento brasileiro'. Novos Estudos-CEBRAP, 81: 33-46.

Grynszpan, Mario. 2009. A afirmação do agronegócio: novos agentes e representações do rural. Paper presented at the 33rd Anpocs Annual Meeting. Caxambu: ANPOCS.

Gilbert, Christopher L. 2010. 'How to understand high food prices'. Journal of Agricultural Economics, 61(2): 398-425.

Heredia, Beatriz, Moacir Palmeira and Sergio Pereira Leite. 2010. 'Sociedade e economia do "agronegócio” no Brasil.' Revista Brasileira de Ciências Sociais, 25(74): 159-196.

Irwin, Scott H., Dwight R. Sanders, and Robert P. Merrin. 2009. 'Devil or angel? The role of speculation in the recent commodity price boom (and bust)'. Journal of Agricultural and Applied Economics, 41(02) (August): 377-391.

Kahneman, Daniel. 2011. Thinking, fast and slow. New York: Macmillan. 
Leite, Sergio Pereira and Sérgio Sauer. 2011. 'Expansión de agronegocios, mercado de tierras y extranjerización de la propiedad rural em Brasil'. Mundo Siglo XXI, 7(26): 43-63.

Leite, Sergio Pereira and Valdemar Wesz. 2013. 'Les dynamiques foncières et l'expansion de l'agro-industrie du soja au Brésil'. Cahiers Agricultures, 22(1): 39-45.

2016. Brazilian agribusiness, public policies and development strategies: soybean expansion in Mato Grosso. New York: GC/CUNY. Unpublished.

Lima, Divina A L. 2010. Estrutura e expansão da agroindústria canavieira no Sudoeste goiano: impactos no uso do solo e na estrutura fundiária a partir de 1990. Phd Thesis, Campinas, IE/UNICAMP.

Lima, Maria S B. 2010. Políticas públicas e território: uma discussão sobre os determinantes da expansão da soja no sul do Amazonas. Phd Thesis-CPDA/UFRRJ, Rio de Janeiro.

Mendonça, Sônia R de. 2005. 'Estado e hegemonia do Agronegócio no Brasil'. História e Perspectivas, 32/33: 91-132.

National Institute of Colonization and Agrarian Reform (INCRA). 2013. Instrução Normativa/ INCRA/ no. 76 de 23 de Agosto de 2013. Brasilia: INCRA.

Oliveira, Ariovaldo U. 2010. 'A questão da aquisição de terras por estrangeiros no Brasil-um retorno aos dossiês'. Agrária (Online), 12: 3-113.

Pretto, José Miguel. 2009. 'Imóveis rurais sob propriedade de estrangeiros no Brasil'. Research report for technical co-operation programme 'Apoio às políticas e à participação social no desenvolvimento rural' (PCT IICA/NEAD). Brasília: NEAD.

Rangel, Ignácio. 1986. 'A questão da terra'. Revista de Economia Política, 6(4): 71-77.

Rede Social de Justiça e Direitos Humanos, GRAIN, Inter Pares and Solidarity Sweden - Latin America. 2015. Foreign pension funds and land grabbing in Brazil. At: https://www.grain.org/article/ entries/5336-foreign-pension-funds-and-land-grabbing-in-brazil [Accessed on March 26 2017].

Safransky, Sara and Wendy Wolford. 2011. 'Contemporary land grabs and their alternatives in the Americas'. Paper presented at the International Conference on Global Land Grabbing 6-8 April. Brighton, University of Sussex.

Salim, Celso Amorim. 1986. 'As políticas econômica e tecnológica para o desenvolvimento agrário das áreas de cerrados no Brasil: avaliação e perspectivas'. Cadernos de Difusão de Tecnologia, 3 (2): 297-342.

Sauer, Sérgio and Sergio P Leite. 2012. 'Agrarian structure, foreign investment in land, and land prices in Brazil.' The Journal of Peasant Studies, 39(3-4): 873-898.

Shiller, Robert J. 2015. Irrational exuberance. Princeton University Press.

Tang, Ke and Wei Xiong. 2012. 'Index investment and the financialization of commodities.' Financial Analysts Journal, 68(5): 54-74.

Teachers Insurance and Annuity Association-College Retirement Equities Fund (TIAA-CREF). 2012. Responsible investment in farmland. New York: TIAA-CREF.

Wilkinson, John. 2009. 'The globalization of agribusiness and developing world food systems'. Monthly Review, 61(4): 38.

Wilkinson, John and Selena Herrera. 2010. 'Biofuels in Brazil: debates and impacts'. The Journal of Peasant Studies, 37(4): 749-768. 
Wilkinson, John, Bastiaan Reydon and Alberto Di Sabbato. 2012. 'Concentration and foreign ownership of land in Brazil in the context of global land grabbing. Canadian Journal of Development Studies/Revue canadienne détudes du développement, 33(4): 417-438.

World Bank. 2010. Rising global interest in farmland: Can it yield sustainable and equitable benefits? Washington D.C.: World Bank.

Zaia, Cristiano. 2016. Cresce o apoio à compra de terras por estrangeiros. Valor Econômico, 11 July. 


\section{Annex (Tables and Figures)}

Figure 1 - Area with soybean crops per micro-region in Brazil
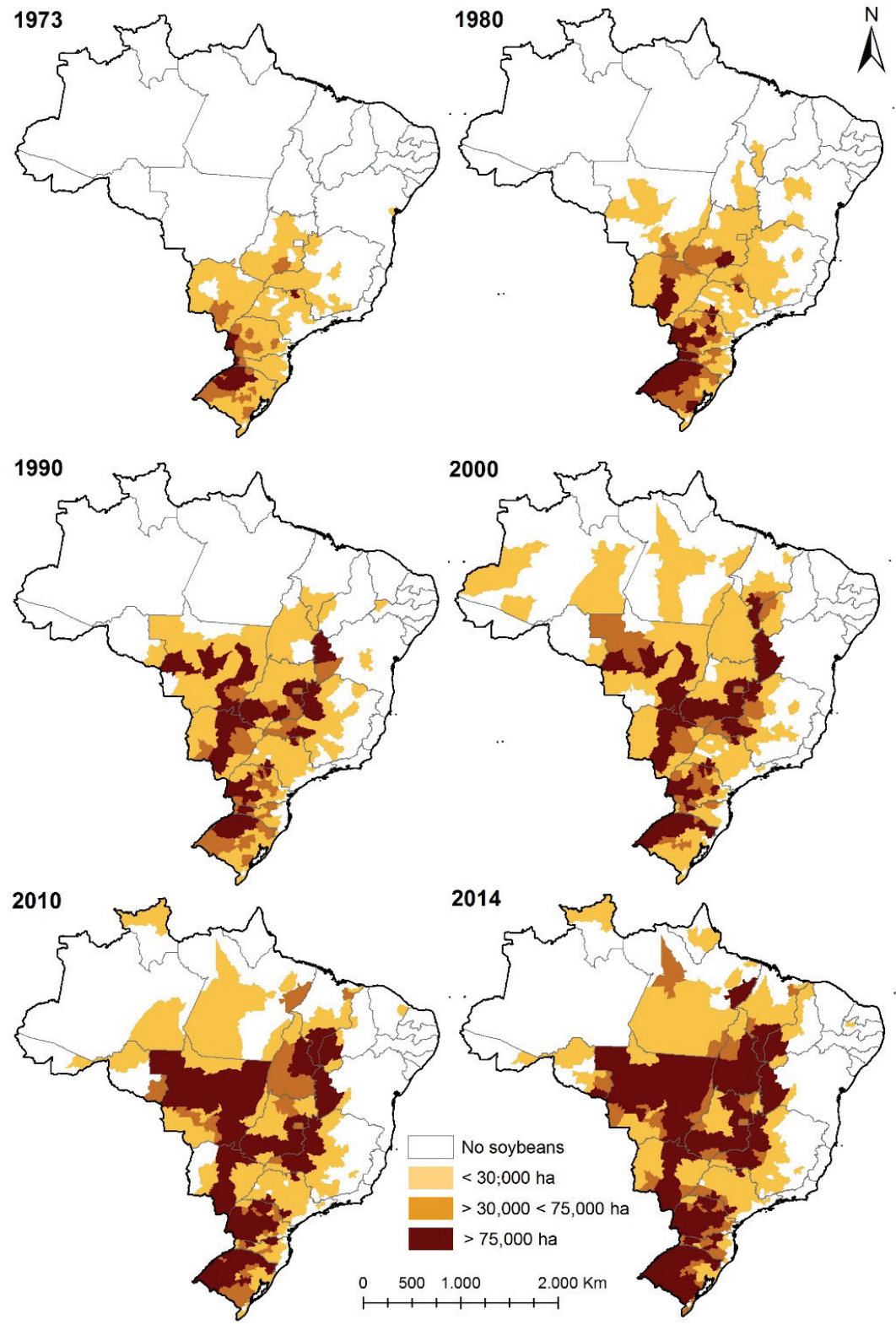

Source: Elaborated by Valdemar Wesz Jr. apud Leite and Wesz Jr. (2016) with data from the Brazilian Institute of Geography and Statistics (IBGE). 
Figure 2 - Area with sugar cane crops per micro-region in Brazil
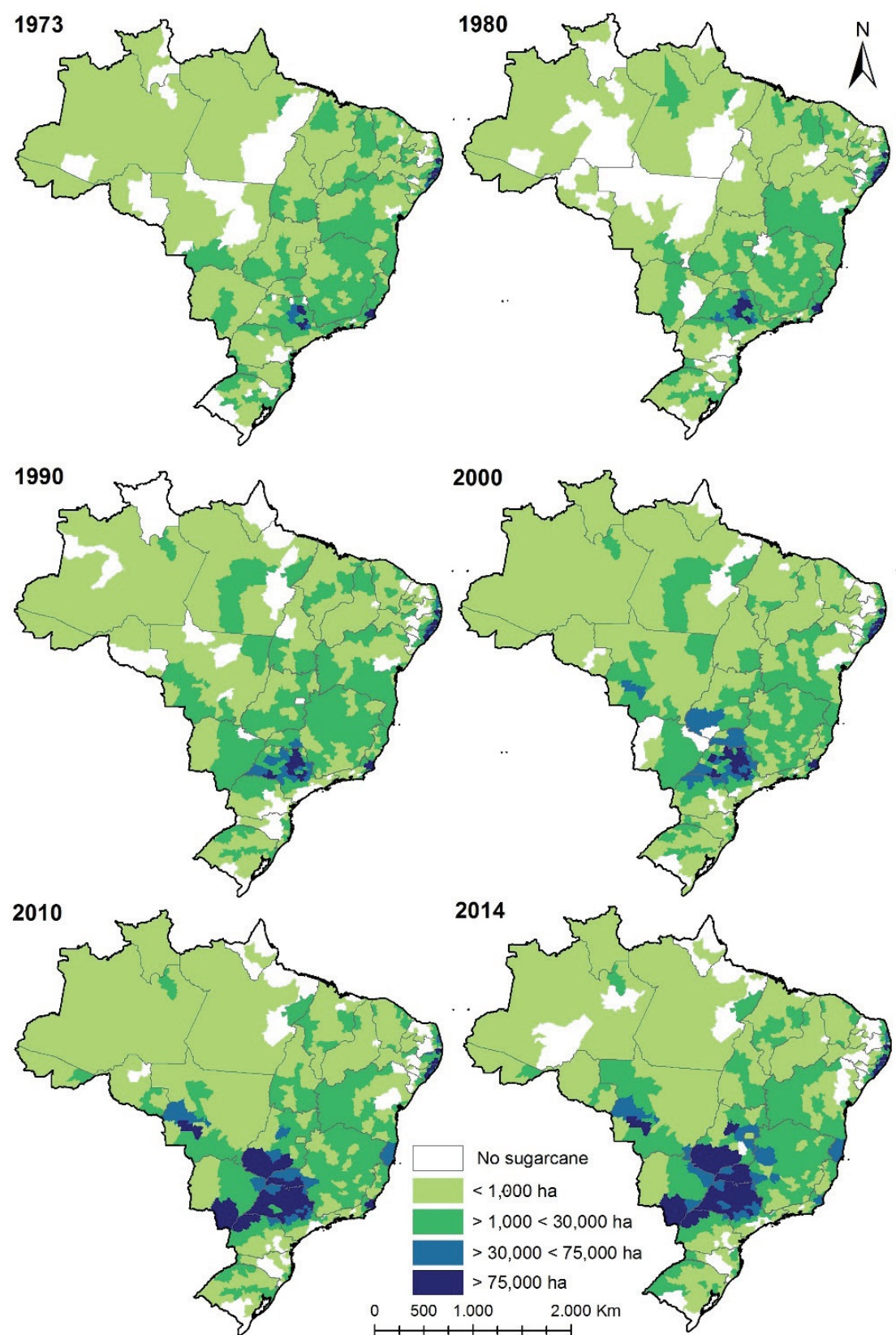

2014

Source: Elaborated by Valdemar Wesz Jr. apud Leite and Wesz Jr. (2016) with data from the Brazilian Institute of Geography and Statistics (IBGE). 
Figure 3 - Relation between prices for farming land, soybean, beef (per measuring arroba unit), IBOVESPA and IPCA indexes, 1995/2013
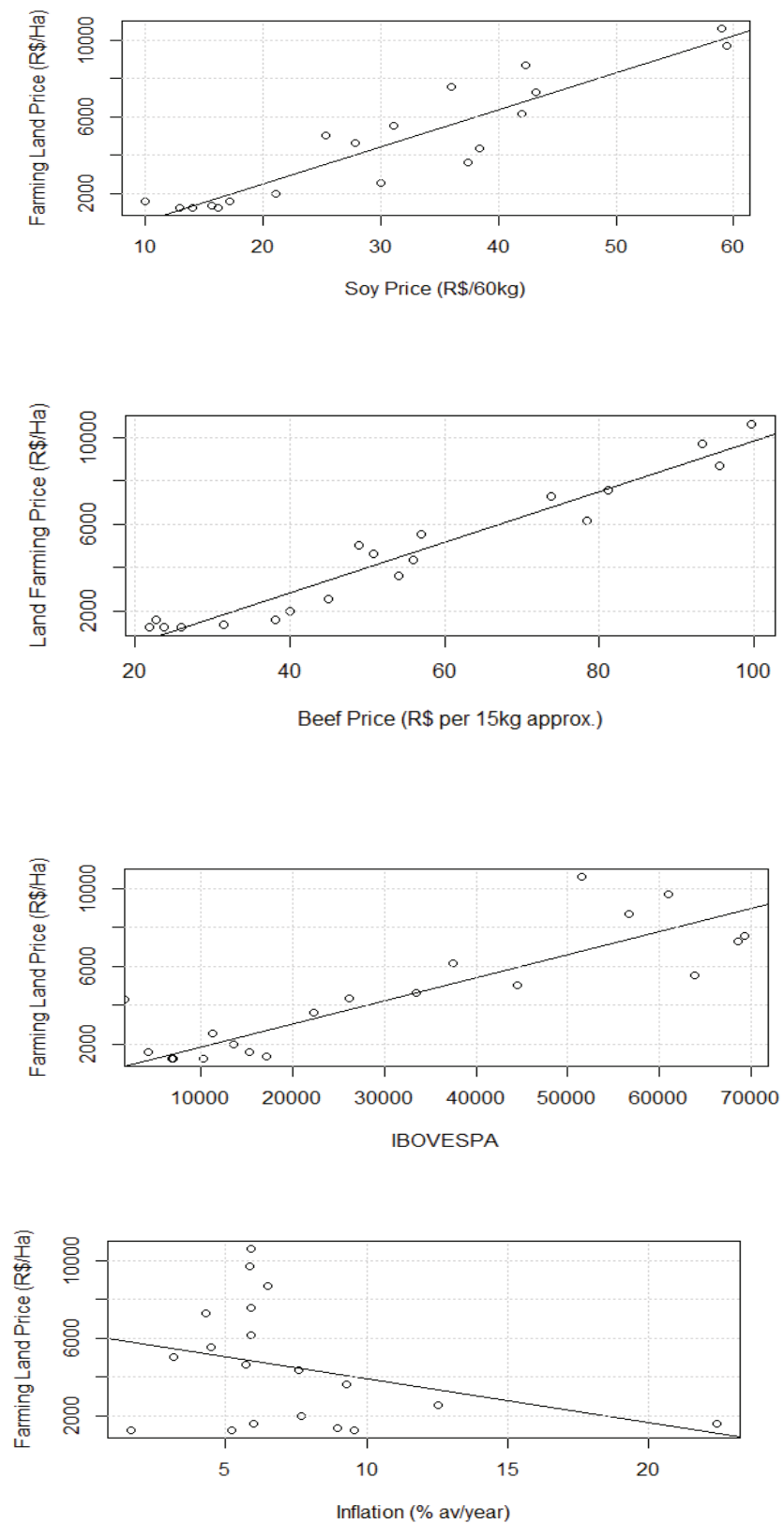

Source: FGVDados \& IPEAData 
Figure 4 - Price indexes of commodities for 2000-2016

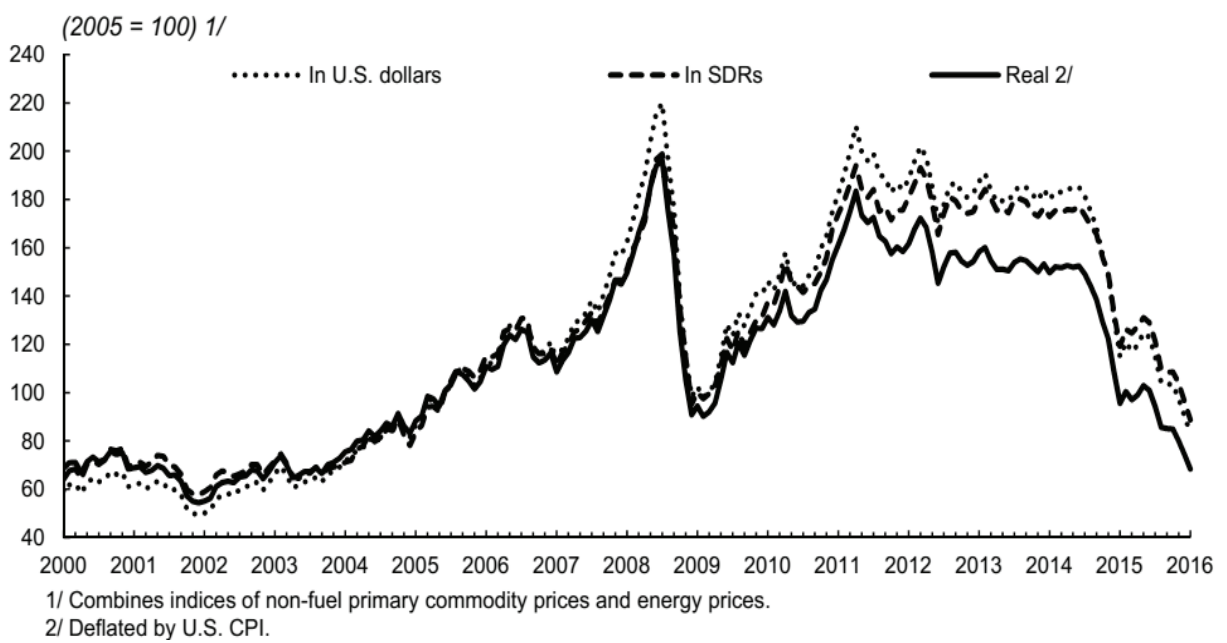

Source: International Monetary Fund (IMF Commodity Price Indices)

Figure 5 - Grain production in millions of tons - Brazil 2000/2015

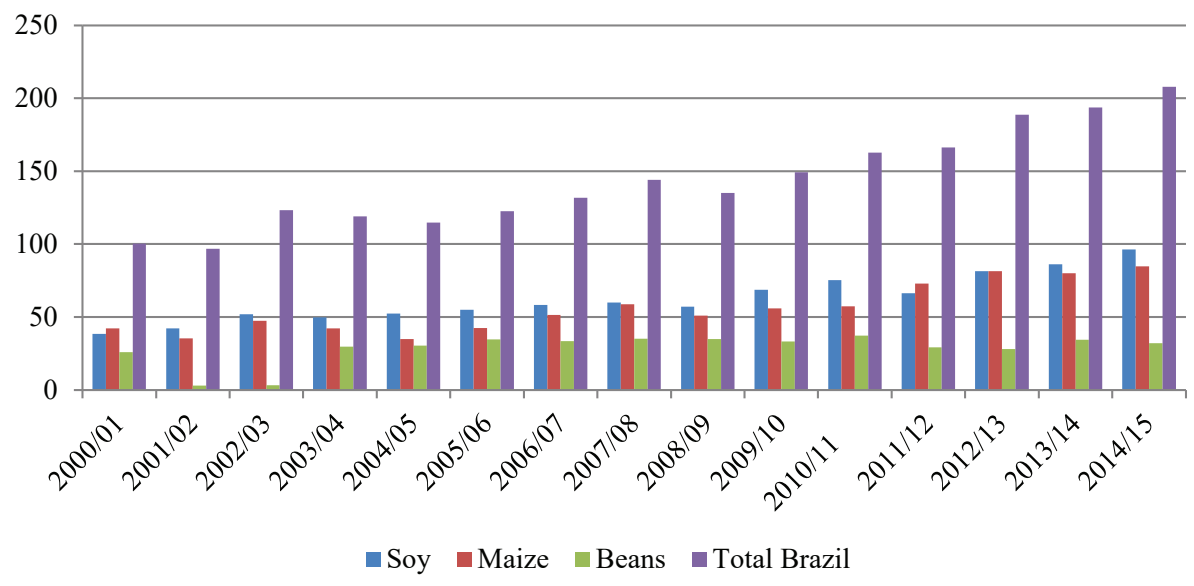

Source: National Company of Food Supply (Companhia Nacional de Abastecimento Alimentar - CONAB) 
Figure 6 - Area with grain crops in millions of hectares 2000-2015

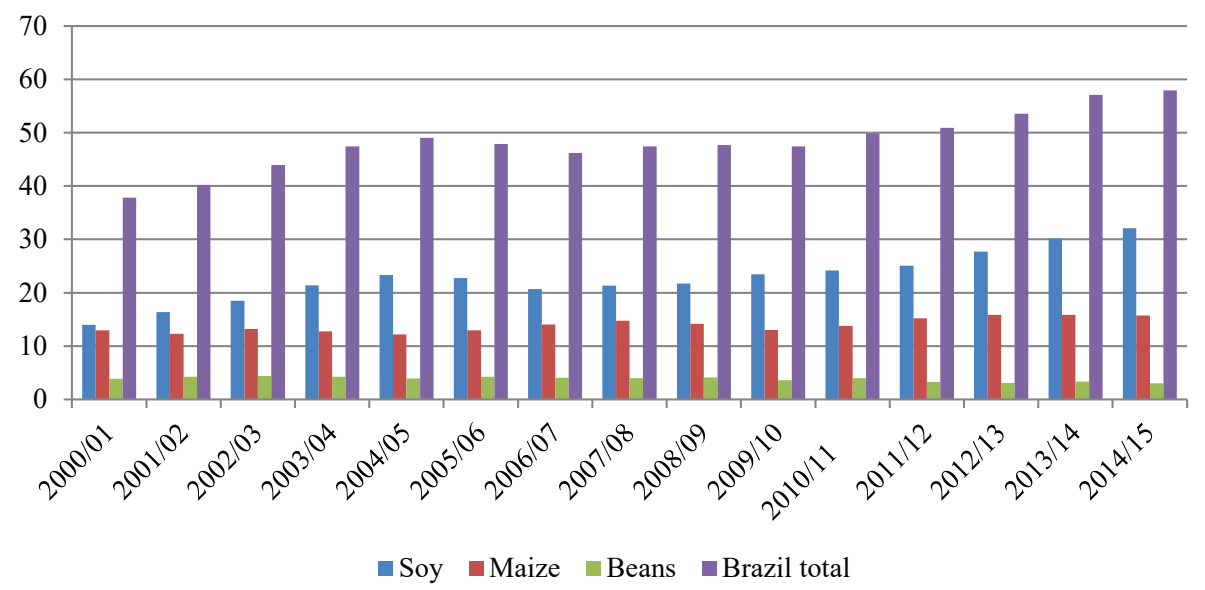

Source: National Company of Food Supply (Companhia Nacional de Abastecimento Alimentar - CONAB)

Figure 7 - Investment in land in Brazil funded by TIAA-CREF - 2012

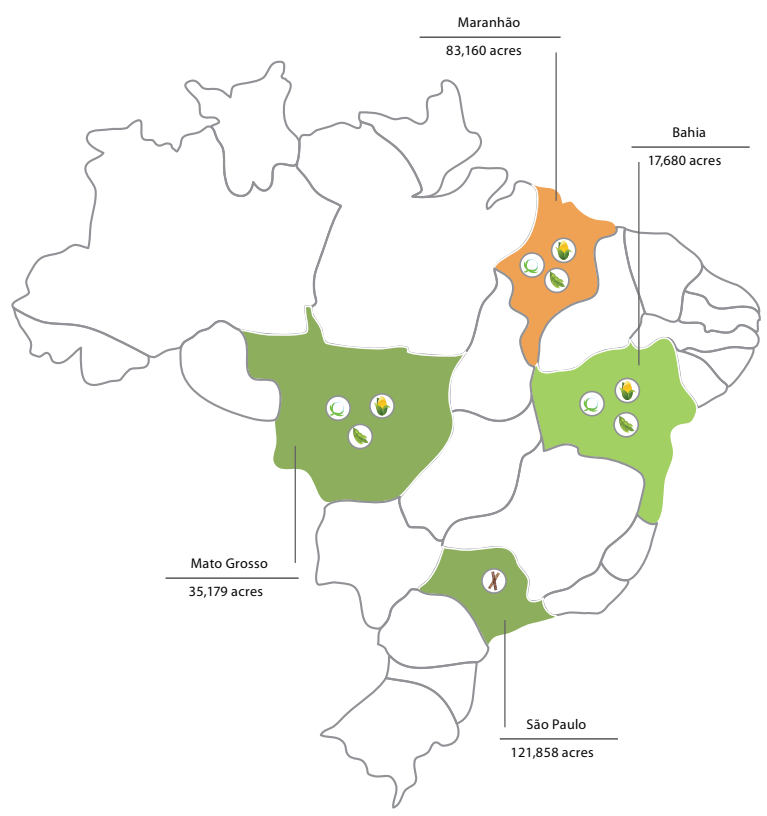

Total acreage as of 6/30/12

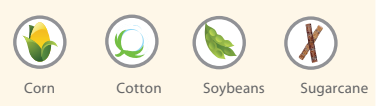

Source: TIAA-CREF (2012)

$10,000 \mathrm{ac}=4,046.856 \mathrm{ha}$ 
Table 1 Descriptive statistics of land price in Brazil in current $\mathbf{R} \$ \mathbf{h a}$

\begin{tabular}{lrrr}
\hline & $\mathbf{2 0 1 0}$ & $\mathbf{2 0 1 4}$ & \multicolumn{1}{c}{$\mathbf{2 0 1 5}$} \\
\hline Mean & $4,755.64$ & $9,530.31$ & $10,082.79$ \\
Median & $3,150.00$ & $7,175.00$ & $8,000.00$ \\
St. deviation & $5,194.68$ & $9,064.01$ & $9,365.26$ \\
Minimum & 50.00 & 152.00 & 175.00 \\
Maximum & $39,083.00$ & $49,917.00$ & $54,000.00$ \\
1st Qu. & 942.00 & $2,391.50$ & $2,800.00$ \\
3rd Qu. & $6,433.00$ & $13,483.25$ & $14,500.00$ \\
IQR & $5,491.00$ & $11,041.25$ & $11,700.00$ \\
\hline
\end{tabular}

Source: Informa Economics FNP

Table 2 - Descriptive statistics of land price for main Brazilian macro-regions 2010/2014/2015 (current values in $R \mathbf{S} / \mathrm{ha}$ )

\begin{tabular}{lrrrrrrr}
\hline Region & Year & \multicolumn{1}{c}{ Min } & \multicolumn{1}{c}{ 1st Qu. } & \multicolumn{1}{c}{ Median } & \multicolumn{1}{c}{ Mean } & \multicolumn{1}{l}{ 3rd Qu. } & \multicolumn{1}{l}{ Max. } \\
\hline \multirow{3}{*}{ South } & 2010 & 908.00 & $5,375.00$ & $7,967.00$ & $10,060.00$ & $12,540.00$ & $39,080.00$ \\
& 2014 & $3,233.00$ & $11,166.00$ & $16,167.00$ & $19,527.00$ & $23,800.00$ & $49,917.00$ \\
\multirow{4}{*}{ Southeast } & 2015 & $3,500.00$ & $11,833.00$ & $17,667.00$ & $20,635.00$ & $26,250.00$ & $54,000.00$ \\
\cline { 2 - 8 } & 2010 & 350.00 & $3,900.00$ & $6,792.00$ & $8,121.00$ & $11,450.00$ & $23,670.00$ \\
& 2014 & 798.00 & $8,804.00$ & $13,133.00$ & $15,070.00$ & $19,708.00$ & $41,333.00$ \\
\multirow{3}{*}{ Central-West } & 2015 & $1,167.00$ & $9,167.00$ & $14,500.00$ & $15,765.00$ & $20,000.00$ & $41,500.00$ \\
\cline { 2 - 8 } & 2010 & 200.00 & $1,700.00$ & $3,000.00$ & $3,623.00$ & $5,233.00$ & $11,200.00$ \\
& 2014 & 407.00 & $3,817.00$ & $7,183.00$ & $8,608.00$ & $12,516.00$ & $33,750.00$ \\
Northeast & 2015 & 420.00 & $4,116.00$ & $8,000.00$ & $9,212.00$ & $12,833.00$ & $36,500.00$ \\
\hline \multirow{3}{*}{ North } & 2010 & 50.00 & 400.00 & $1,333.00$ & $2,206.00$ & $3,342.00$ & $11,750.00$ \\
& 2014 & 152.00 & 843.50 & $3,150.00$ & $4,366.00$ & $6,933.00$ & $18,000.00$ \\
& 2015 & 175.00 & $1,000.00$ & $3,100.00$ & $4,557.00$ & $7,500.00$ & $19,500.00$ \\
\hline
\end{tabular}

Source: Informa Economics FNP

Table 3 - Descriptive statistics of land price in Brazil in US\$/ha

\begin{tabular}{lcrcccc}
\hline & Min & \multicolumn{1}{c}{ 1st Qu. } & Median & Mean & 3rd Qu. & Max. \\
\hline $\mathbf{2 0 1 0}$ & 28.40 & 535.10 & $1,789.40$ & $2,701.60$ & $3,654.40$ & $22,202.00$ \\
$\mathbf{2 0 1 4}$ & 64.59 & $1,023.51$ & $3,049.08$ & $4,049.99$ & $5,715.60$ & $21,212.69$ \\
$\mathbf{2 0 1 5}$ & 52.54 & 840.59 & $2,401.68$ & $3,026.96$ & $4,353.05$ & $16,211.35$ \\
\hline
\end{tabular}

Source: Informa Economics FNP 
Table 4 -Correlation between price for farming land and prices for soybean, beef, IBOVESPA, IPCA, Exchange rate, Selic interest rate in Brazil from 1995 to 2013

\begin{tabular}{|c|c|c|c|c|c|c|}
\hline & $\begin{array}{l}\text { Price of farming } \\
\text { land (R\$/ha) }\end{array}$ & $\begin{array}{l}\text { Price of soybe- } \\
\text { an ( } 60 \mathrm{~kg} \text { bag) }\end{array}$ & IBOVESPA & $\begin{array}{l}\text { Price of beef } \\
\text { (arroba mea- } \\
\text { suring unit) }\end{array}$ & $\begin{array}{l}\text { Inflation } \\
\text { (\% av. } \\
\text { per year - } \\
\text { IPCA) }\end{array}$ & $\begin{array}{l}\text { Exchan- } \\
\text { ge rate }\end{array}$ \\
\hline $\begin{array}{l}\text { Soybean } \\
\text { price ( } 60 \mathrm{~kg} \\
\text { bag) }\end{array}$ & $\begin{array}{l}0.923 \\
(0.000)\end{array}$ & -- & -- & -- & -- & -- \\
\hline IBOVESPA & $\begin{array}{l}0.886 \\
(0.000)\end{array}$ & $\begin{array}{l}0.748 \\
(0.000)\end{array}$ & -- & -- & -- & -- \\
\hline $\begin{array}{l}\text { Price of beef } \\
\text { (arroba mea- } \\
\text { suring unit) }\end{array}$ & $\begin{array}{l}0.971 \\
(0.000)\end{array}$ & $\begin{array}{l}0.941 \\
(0.000)\end{array}$ & $\begin{array}{l}0.842 \\
(0.000)\end{array}$ & -- & -- & -- \\
\hline IPCA & $\begin{array}{l}-0.326 \\
(0.174)\end{array}$ & $\begin{array}{l}-0.292 \\
(0.226)\end{array}$ & $\begin{array}{l}-0.450 \\
(0.053)\end{array}$ & $\begin{array}{l}-0.322 \\
(0.179)\end{array}$ & -- & -- \\
\hline $\begin{array}{l}\text { Exchange } \\
\text { rate }\end{array}$ & $\begin{array}{l}0.222 \\
(0.361)\end{array}$ & $\begin{array}{l}0.466 \\
(0.045)\end{array}$ & $\begin{array}{l}0.093 \\
(0.706)\end{array}$ & $\begin{array}{l}0.345 \\
(0.148)\end{array}$ & $\begin{array}{l}-0.033 \\
(0.983)\end{array}$ & -- \\
\hline Selic rate & $\begin{array}{l}-0.754 \\
(0.000)\end{array}$ & $\begin{array}{l}-0.767 \\
(0.000)\end{array}$ & $\begin{array}{l}-0.794 \\
(0.000)\end{array}$ & $\begin{array}{l}-0.795 \\
(0.000)\end{array}$ & $\begin{array}{l}0.698 \\
(0.001)\end{array}$ & $\begin{array}{l}-0.426 \\
(0.069)\end{array}$ \\
\hline
\end{tabular}

Source: Elaborated by the authors with data from FGVDados \& IPEAData Pearson correlation index ( $p$-value in parenthesis)

Table 5 - Percentage of land purchase (number of properties and area size) by foreigners in Brazil (1900-2000)

\begin{tabular}{lrrrr}
\hline Decades & \% Units & \% accumulated & \% Area & \% accumulated \\
\hline 1900 & 0.012 & 0.012 & 0.0004 & 0.0004 \\
1910 & 0.047 & 0.058 & 0.064 & 0.065 \\
1920 & 0.143 & 0.202 & 0.170 & 0.235 \\
1930 & 0.415 & 0.617 & 0.309 & 0.544 \\
1940 & 1.207 & 1.824 & 0.971 & 1.514 \\
1950 & 4.015 & 5.839 & 2.551 & 4.065 \\
1960 & 8.773 & 14.612 & 6.194 & 10.259 \\
1970 & 17.421 & 32.033 & 15.040 & 25.298 \\
1980 & 29.888 & 61.921 & 27.940 & 53.238 \\
1990 & 18.201 & 80.122 & 25.925 & 79.163 \\
2000 & 18.783 & 98.904 & 20.152 & 99.315 \\
Absence de dates & 1.096 & 100.000 & 0.685 & 100.000 \\
Total & 100.000 & & 100.000 & \\
\hline
\end{tabular}

Source: SNCR/Incra (apud Pretto 2009: 21) 
Table 6 - Number and area size of rural properties owned by foreigners - Brazil - 2010

\begin{tabular}{|c|c|c|c|c|}
\hline States & N. of properties & $\%$ & Area (ha) & $\%$ \\
\hline Rondônia & 119 & 0.35 & $29,242.00$ & 0.67 \\
\hline Acre & 26 & 0.08 & $13,799.68$ & 0.32 \\
\hline Amazonas & 307 & 0.89 & $232,021.68$ & 5.33 \\
\hline Roraima & 66 & 0.19 & $27,729.49$ & 0.64 \\
\hline Pará & 1,143 & 3.33 & $235,628.39$ & 5.42 \\
\hline Amapá & 15 & 0.04 & $6,228.00$ & 0.14 \\
\hline Tocantins & 181 & 0.53 & $109,517.18$ & 2.52 \\
\hline Maranhão & 184 & 0.54 & $70,135.35$ & 1.61 \\
\hline Piauí & 82 & 0.24 & $58,770.32$ & 1.35 \\
\hline Ceará & 401 & 1.17 & $34,734.45$ & 0.80 \\
\hline Rio Gde Norte & 128 & 0.37 & $20,806.69$ & 0.48 \\
\hline Paraíba & 248 & 0.72 & $6,828.47$ & 0.16 \\
\hline Pernambuco & 368 & 1.07 & $9,667.19$ & 0.22 \\
\hline Alagoas & 101 & 0.29 & $13,577.66$ & 0.31 \\
\hline Sergipe & 81 & 0.24 & $3,439.45$ & 0.08 \\
\hline Bahia & 2,192 & 6.38 & $368,888.05$ & 8.48 \\
\hline Minas Gerais & 2,639 & 7.68 & $491,548.57$ & 1.30 \\
\hline Espírito Santo & 304 & 0.88 & $19,770.66$ & 0.45 \\
\hline Rio de Janeiro & 2,110 & 6.14 & $85,284.78$ & 1.96 \\
\hline São Paulo & 12,291 & 35.76 & $491,437.42$ & 11.30 \\
\hline Paraná & 5,130 & 14.93 & $299,061.84$ & 6.88 \\
\hline Santa Catarina & 1,290 & 3.75 & $54,605.77$ & 1.26 \\
\hline Rio Gde Sul & 1,895 & 5.51 & $113,801.07$ & 2.62 \\
\hline Mato Grosso Sul & 781 & 2.27 & $473,325.65$ & 10.88 \\
\hline Mato Grosso & 1,229 & 3.58 & $844,279.92$ & 19.41 \\
\hline Goiás & 843 & 2.45 & $230,629.91$ & 5.30 \\
\hline Distrito Federal & 217 & 0.63 & $4,314.36$ & 0.10 \\
\hline Total Brazil & 34,371 & 100.00 & $4,349,074.00$ & 100.00 \\
\hline
\end{tabular}

Source: Incra. Update from May 2010. Data was adjusted by the authors (cf. Sauer and Leite 2012) 
Table 7 - Foreign Direct Investment in the Country - 2010 stock. Distribution per economic activity sector of company operating in Brazil (US\$ million)

\begin{tabular}{|c|c|c|c|}
\hline Items & $\begin{array}{l}\text { Capital } \\
\text { Participation }\end{array}$ & $\begin{array}{l}\text { Inter-company } \\
\text { loans }\end{array}$ & Total \\
\hline Total & 579,627 & 80,881 & 660,507 \\
\hline Agriculture, livestock and mineral extraction & 92,711 & 18,665 & 111,376 \\
\hline Natural gas and oil extraction & 49,409 & 6,855 & 56,264 \\
\hline Metallic minerals extraction & 35,077 & 5,985 & 41,061 \\
\hline Agriculture, livestock, and related services & 3,770 & 2,630 & 6,400 \\
\hline Other & 4,456 & 3,195 & 7,651 \\
\hline Industry & 230,435 & 32,414 & 262,849 \\
\hline Drinks & 52,220 & 173 & 52,393 \\
\hline Metallurgy & 27,403 & 5,800 & 33,202 \\
\hline Cars, towing vehicles and body parts & 28,445 & 2,261 & 30,706 \\
\hline Chemical products & 24,970 & 4,879 & 29,848 \\
\hline Food products & 13,127 & 2,479 & 15,606 \\
\hline Tobacco-related products & 13,850 & 313 & 14,163 \\
\hline Machinery and equipment & 10,577 & 2,187 & 12,764 \\
\hline Pharmochemical and pharmaceutical products & 8,708 & 737 & 9,445 \\
\hline Cellulose, paper and paper products & 7,059 & 1,705 & 8,764 \\
\hline Coke, oil by-products and biofuels & 5,375 & 2,943 & 8,318 \\
\hline Rubber and plastic products & 6,892 & 1,423 & 8,316 \\
\hline Metal products & 6,605 & 1,154 & 7,759 \\
\hline IT equipment, electronic and optical products & 5,369 & 2,290 & 7,659 \\
\hline Non-metallic mineral products & 4,437 & 428 & 4,865 \\
\hline Electric machinery, devices and materials & 3,994 & 702 & 4,696 \\
\hline Other industries & 11,403 & 2,941 & 14,344 \\
\hline Services & 256,481 & 29,802 & 286,282 \\
\hline Financial services and related activities & 98,081 & 1,435 & 99,516 \\
\hline Telecommunications & 40,647 & 5,105 & 45,752 \\
\hline Trading, except vehicles & 24,993 & 8,414 & 33,407 \\
\hline Electricity, gas and other services & 26,958 & 1,145 & 28,103 \\
\hline Real estate activities & 12,339 & 1,674 & 14,013 \\
\hline Insurance, reinsurance, complementary pensions health plans & 9,661 & 167 & 9,828 \\
\hline Construction work & 6,280 & 222 & 6,502 \\
\hline Catering costs & 2,570 & 3,897 & 6,467 \\
\hline IT services & 4,466 & 1,197 & 5,663 \\
\hline Clerical services and corporate outsourcing & 4,449 & 754 & 5,203 \\
\hline Activities at head offices and consultancy management & 4,084 & 1,026 & 5,110 \\
\hline Storage and transport-related activities & 4,125 & 657 & 4,782 \\
\hline Other services & 17,828 & 4,108 & 21,936 \\
\hline
\end{tabular}

Source: Brazilian Central Bank 
Table 8 - Land acquired by international capital (above 10,000 hectares) - Brazil - 2007 /2014

\begin{tabular}{|c|c|c|c|c|c|c|}
\hline Capital & $\begin{array}{l}\text { Companies } \\
\text { 1st sector }\end{array}$ & $\begin{array}{l}\text { Companies 2nd } \\
\text { sector }\end{array}$ & Production & Area (ha) & Year & State \\
\hline Chile & Centaurus Holdings & Klabin/Arauco & Forest & 107,000 & 2012 & PR \\
\hline Chile & CMPC Riograndense & CMPC & Forest & 100,000 & 2012 & RS \\
\hline United States & RADAR S.A. & TIAA-CREF & Agriculture & 84,000 & 2010 & $\mathrm{SP}$ \\
\hline Japan & Multigrain S.A. & Mitsui & Soy/ Cotton & 80,000 & 2007 & $\mathrm{BA}$ \\
\hline India & Shree Renuka Sugars & - & Sugar & 78,000 & 2010 & PR \\
\hline Luxemburg & Adecoagro & Adecoagro Ltd. & $\begin{array}{l}\text { Soy/ Cotton/ Corn/ } \\
\text { Coffee/ Sugar }\end{array}$ & 55,000 & 2005 & MS \\
\hline Holland & RDF & FIAM N.V. & Forest & 40,000 & 2007 & AM \\
\hline Jersey & Agrifirma Brasil & Genagro Ltd. & Soy/ Corn & 38,841 & 2009 & $\mathrm{BA}$ \\
\hline Argentina & BrasilAgro & CRESUD & Agriculture & 37,182 & 2007 & BA \\
\hline Holland & Floresteca Holding & - & Forest & 37,000 & - & MT \\
\hline Argentina & BrasilAgro & CRESUD & Agriculture & 31,606 & 2007 & $\mathrm{BA}$ \\
\hline Canada & Brookfield & Brookfield Asset & Agriculture & 30,000 & 2005 & MT \\
\hline Argentina & BrasilAgro & CRESUD & Forest & 24,247 & 2007 & MG \\
\hline Japan & SLC-MIT & Mitsui & Soy/ Cotton & 22,000 & 2013 & $B A$ \\
\hline Jersey & Agrifirma Brasil & Genagro Ltd. & Agriculture & 20,183 & 2008 & BA \\
\hline Canada & Brookfield & Brookfield Asset & Agriculture & 17,860 & 2008 & MT \\
\hline Argentina & BrasilAgro & CRESUD & Agriculture & 17,799 & 2008 & BA \\
\hline Canada & Brookfield & Brookfield Asset & Sugar & 13,089 & 2000 & SP \\
\hline Canada & Brookfield & Brookfield Asset & Agriculture & 12,920 & 2007 & MT \\
\hline Canada & Brookfield & Brookfield Asset & Agriculture & 12,777 & 2007 & MS \\
\hline Jersey & Agrifirma Brasil & Genagro Ltd. & Soy/Corn & 12,287 & 2008 & BA \\
\hline Canada & Brookfield & Brookfield Asset & Agriculture & 11,925 & 2007 & MS \\
\hline France & CalyxAgro & Louis Dreyfuss & Soy/ Cotton & 10,853 & 2009 & $\mathrm{BA}$ \\
\hline Japan & Multigrain S.A. & Mitsui & Soy/ Cotton & 10,000 & 2007 & MA \\
\hline
\end{tabular}

Source: Elaborated by Carla Morsh with data from the Land Matrix. 


\section{About the authors}

Georges Flexor is Associate Professor at the Department of Economics of the Multidisciplinary Institute of the Federal Rural University of Rio de Janeiro (UFRRJ) and Professor of the graduate programme in Social Sciences for Development, Agriculture, and Society (CPDA/UFRRJ). He is a researcher at the Observatory of Public Policies for Agriculture (OPPA/UFRRJ) and also at the National Institute of Policies, Strategy and Development (INCT/PPED), Brazil. He has experience in Political Economy of Development and Public Policy. His main research topics are: institutional analysis of policy, political economy of development, and food and energy policy.

Sergio Pereira Leite is Associate Professor of the graduate programme in Social Sciences for Development, Agriculture, and Society of the Federal Rural University of Rio de Janeiro (CPDA/UFRRJ), and co-ordinator of both the Observatory on Public Policies for Agriculture (OPPA/UFRRJ) and the study group on 'Social Changes, Agribusiness and Public Policies' (GEMAP/UFRRJ), Brazil. He has received research grants from Brazilian agencies, such as CNPq, FAPERJ, and CAPES, and was Visiting Scholar at The City University of New York (CUNY), USA, as well as Visiting Professor at both the School for Advanced Studies in the Social Sciences (EHESS), France, and the National University of South (UNS), Argentina.

Received on 1 September 2016, and approved for publication on 6 March 2017. https://creativecommons.org/licenses/by-nc/4.0/ 